\title{
The Remix of Technological Advancement, Secularism, Religious Issues and Intellectual Property Rights
}

\author{
Dr. K. Syamala, Dr. Sreenivasa Murthy M.R \& \\ Harshavardhan Yadav (JSD) \\ Centre for Study and Research in IPR (CSRIPR) National University of Study and Research in Law, Ranchi \\ (NUSRL, Ranchi) Polytechnic Campus, BIT Mesra, Ranchi - 835215 (Jharkhand)
}

\begin{abstract}
Secularism in India is neither pro-religious nor anti-religious but provides a space of respect for religious feelings. The technological advancement particularly in the fields of biotechnology is creating a little disturbance in the balance maintained by the Constitution of India in this diversified country. Many issues such as genetically modified food, genetically modified organisms, patenting genes and cloning are creating a debate whether the balance is towards the societal progress or towards respecting religious feelings. Being a secular state and respecting religious feelings at the same time, whether our intellectual property rights legislations are competent enough to tackle the issue inside and outside the country is a big debate. Thus, keeping this debate as a baseline the researchers have analyzed the concept of secularism in India along with the provisions in Indian intellectual property legislations which deals with religion. Further, an attempt has been made to address the issue that whether our secular country is opening the gates for technological progress or closing in
\end{abstract} the name of religion.

Keywords: Secularism, Humanism, Hinduism, Biotechnology, Patent, Public order and Morality

\section{Prologue}

'Secularism is a doctrine that morality should be based solely the well-being of mankind in present life, to the exclusion of all considerations in regard to drawn from belief in God ...'

George Holoake (Whitehead \& Conlan, 1978)

Secularism and science is having a long standing connection with each other. Secularism is based on morals which are evolved for the welfare of mankind beyond the belief in God and religion. Humanism is 'any doctrine or set of values which rejects supernaturalism, asserts the essential dignity and worth of each human being, and commits itself to the achievement of individual self-realization and aggregate human welfare through reason and scientific method'(Peter D. Schmid, 1989). The Secular Humanism though is a modern concept having deep roots in the history of the western world. The use of the term Secular Humanism accelerated after the formation of the American Humanist Association in 1933. After the evolution of Darwin's theory in 1859 regarding to theory of evolution, changed the beliefs and faiths of the human being in the theological stage of human history and advanced towards the age of science. The Secular Humanist Declaration was the first published document in 1980 which defined and defended the balance between the religious freedom and secularism. It insisted that "Democratic Secular Humanism is too important for human civilization to abandon" (Peter D. Schmid, 1989). The American Constitution first amendment also was caught hold by the controversy while balancing the religious feelings and the secularism.

Indian constitution is based on the four pillars such as sovereign, socialist, secular and democratic concepts. India being a democratic country provoked the thought in the legislators mind that without being socialist and secular, it cannot achieve the ends of democracy which forced the $42^{\text {nd }}$ amendment to the Indian constitution in 1976 to add the "socialist and secular". The S.R.Bommai Vs. Union of India, AIR 1994 SC 1918 clearly mentioned that secularism is the integral part of the Indian constitution. The basic ideology behind the introduction of concept of secularism in India is not to give importance to religion but to give importance to the interest of the individual in religion with reasonable restrictions. It upholds the respect towards religious beliefs and sentiments of the Indian citizens and takes care of their grievances if any causing disturbance to their reasonable beliefs. The secularism in India has clearly declared that India is not belonging or influenced by any particular religion.

The new technological advancement emerging in the world in the name of biotechnology is a kind of boomerang which is making magic in the field of agriculture, medicine, food and human genetics. The gene transfer technology and genomic science has revealed magnificent results in overcoming the rare and popular diseases and malnutrition etc., for example, the Golden rice which is 
an outcome of biotechnology is enriched with vitamin A where the children are dying with deficiency and Bt Cotton where the agricultural farmers who were yielding cotton overcome the sufferings and loss caused due to pesticides and "bollworm". Genomics which resulted into the Human Genome Project which mapped the entire human genome revealed the secret behind the human genome and explored the functioning of the human genes and their characteristics. Now it is possible to identify which gene is responsible for which disease and curing or removing that gene is enough to cure the disease instead of experimenting on the entire body.

The main debatable issue revolving around the biotechnology raised by many religious institutions and priests is thought provoking. It raised the issues such as patenting of human genes, human cloning, genetically modified food and organisms, stem cell research etc., which is an outcome of biotechnology is going to interfere in the sovereignty of the mankind who is the sole proprietor of the human kind. But the patent holders and the Dedicated Biotechnology Firms (DBFs) are arguing that they are holding property rights only over the isolated genes and the inventions made through biotechnology but not on the genes or the organisms which are in nature per se and at the same time the secularism encourages the welfare of the mankind in the process of evolution rather than blindly relying on the theory of God. The law of nature says that human beings are the proprietors of their own kind and cannot be owned by oneself due to mere discovery of the existing biomaterial in the nature. But whether isolation or discovery of the existing human organisms makes any difference is the debatable question where the secularism, religious beliefs and ethics of the individuals in the society is coming into picture.

\section{Position in World:}

In the beginning days of Darwinism in 1859, there was a hue and cry from the religious institutions that the evolution process of human life and struggle for existence theory will create a debacle in the religious beliefs and faith of the citizens. The evolutionary theory of "vital forces within living things and the inheritance of acquired characteristics" which is the base for the Darwin theory mentions that the characteristics of the new organism will be randomly selected not by the action of the god but by the action of nature. The religious priests and the supporters argued that the history is created by god and the origin of the entire nature is by god and no role of science without the basic creation of god. It is only a tool to understand the creation of god.

From the good olden days there was always a nexus between the god and the law and the people believe in morals which are said to be evolved from the history which is based on the beliefs influenced by religion. When country like United State of America wanted to amend its laws by framing its constitution as 'secular', there was a debate whether country should be free from the influence of religion or it should respect the religion and personal religious feelings of the citizens. It was finally understood that there is no possibility to remove the nexus between the law and the religion because the origin of the law was from the base of religious practices and principles which in turn also became customary principles which are required to the followed as a law which now and in future also inseparably govern the human conduct.

In the later days when the DNA was identified and discovered by the eminent scientists Crick and Watson, the constant life time interaction between genes and the environment was revealed. The cultural and physical environment interacts with the biological sciences as a coefficient, or at least a vector of force, in influencing the total development of the individual. Though in the later days science developed rapidly to know the ultimate depths of the nature such as entire human genome sequence and the experimenting with the nature such as human cloning, but some philosophers believe that it does not explain it totally. The complexity, transcendence, and mystery of the human being remain and thus serve as a reference point of intersection between culture and theology as well as the natural sciences (George P. Smith II, 2005).

In 1973, for the first time, the efforts were taken by the World Council of Churches in the west to study the ethics and religious issues surrounded by the rapid development of science and technology. In the succeeding years, various other studies were commissioned by organizations such as World Conference on Faith and Science and Future but no official standing was given to their findings (George P. Smith II, 2005).

Later when the science started crossing its limits by the process of cloning and gene patenting, stem cell research, genetically modified food etc., the issue became a worldwide importance. The some of the examples of biotechnological inventions effecting the religious intere sts is the dolly sheep which died due to the inexperienced experimentation of the scientists who developed the cloned sheep from the adult cells, and HGP Consortium and Celera Genomics wanted to patent the entire human genome sequence, the blanket ban issued by the Europe over the import of all 
genetically modified organisms where a pig hormone was inserted into the genetically modified beef etc., These various circumstances raised again the curtain for the debate whether can a single discoverer can own the property of the human kind, whether genetically modified food where the gene taken from the animal into the plant or the animal should be allowed without proper labeling etc.,.

United Nations of American and European Union clearly declared by denying funding to stem cell research and denied granting patent to the Entire human genome sequence identified through Human Genome Project jointly by National Human Genome Consortium and private DBF Celera Genomics by mentioning that it is against to the social development which is the underlying concept behind secularism. Whether the emphasis is given to the arguments rose by the religious institutions that a single corporation or person cannot own the property of the entire human mankind by simply discovering the existing thing in nature is a debatable question because of its secular nature. In 2001, when President Bush restricted federal financing for stem cell research, basing partly on the Republican Party's evangelical Christian beliefs, again the criticism was raised about the secular nature of the American constitution.

\section{Position in India:}

India is multi-cultural, multi-linguistic and multi-religious nation where it is highly impossible to maintain a status quo for any one religion. As our constitutional framers adopted the concept of democracy in the beginning, they failed to impart "secularism" while drafting the Constitution in 1947. In 42nd amendment the legislators due to the force of whatever the reasons may be inserted the word "secular" in the preamble of the constitution and gave the meaning as India is not governed by any single religion and is autonomous in its rulings beyond the influence of religion. But at the same time being a democratic country, it is required to maintain a balance to the individual rights so in the fundamental rights Art. 25 to 30 guaranteed the religious freedom to the citizens subject to reasonable restrictions.

As like other countries, India is also suffering with the same trauma of struggle between science and secular humanism. As per the Jeremy Bentham's utilitarian theory, the state has to encourage the innovators who are bringing happiness to the majority number of the citizens. But at the same time, the morality and ethics which were imbedded in the Indian society from the long run cannot be ignored.

In the present debate regarding to stem cell research, there was a big debate whether the majority religion in India i.e., Hinduism is going to obstruct the entrance of such technology or not. Unlike in United States of America, the India faced little less hurdles for the entrance of such ultramodern technology. As per the scholars, Hinduism is less rigid in its approach towards development than Christianity.

In the words of the Birks Professor of Comparative Religions, Professor Arvind Sharma, Montreal McGill University, "Hinduism, for its part, “doesn't share the moral skittishness sometimes displayed by Western Christian thought. If no life is destroyed when taking stem cells from an aborted fetus, and the purpose is not evil, it would not disturb their morality".

To maintain the fundamental principles of our Constitution i.e., "Secularism", i.e., to balance the private rights and the public interest at large, in 2004, the Central Ethics Committee on Human Research of the Indian Council on Medical Research circulated ethical guidelines on how to conduct stem cell research. The Draft Guidelines on Stem cell Research and Regulation draws a clear cut demarcated line by putting a restriction that "termination of pregnancy for obtaining fetus for stem cell research or for transplantation is not permitted. No embryo can be created for the sole purpose of obtaining stem cells". In 2000, prior to the draft guidelines, a report was also rele ased relating to genetic screening i.e., "Ethical guidelines for Biomedical Research on Human Subjects".

Although India is a secular republic, the most of the lifestyle of the Indian citizens is influenced by the Hinduism which is positive towards the scientific advancement because the secularism in India is majorly influenced by the well-being of the people until unless it creates havoc in the large masses of various religions. Unlike Western Christianity influenced society, India influenced by the Hinduism tries to welcome the good for making a better world with the dead line of "public order and morality" which is the balance between secularism and individual religious interests.

Even cloning is also not an objectionable issue in India because the Hindu mythology itself gives lot many examples for cloning and genetic engineering i.e., the birth of lord Ganesha, the birth of Kauravas. As per the studies of scholars, the culture and the religion though physically separated from the influence of law by the insertion of the word "secularism" it is spiritually connected through the ethics and morals inbuilt from the childhood in the citizens by the society. 
But Mohandas Karamachand Gandhi, the Father of our Nation, always used to accuse western medicine, along with much of modern science and technology, of inflicting violence upon human nature and the intellectual property rights system as an obstacle to free flow of knowledge and the reason for growth of conflicts and selfishness which results into destruction and war. His vegetarianism and belief in nonviolence were derived from the Indian traditions, mainly Hinduism. So, the knife has both edges that one side, the mythological stories envisages the early evolution of biotechnology which influences the Indian citizens to accept the new life sciences and on the other side the peace and nonviolence preached by the Gandhi basing on the Indian traditional beliefs is threatening the existence of human being and the narrow monopolistic approach of the western civilization.

The Indian legislators while drafting intellectual property legislations, tried to balance the religious beliefs of the individuals and the secularism. In Indian patent law, the inventions which are contrary to "public order and morality" are not patentable. In geographical indications legislation, plant variety protection legislation, the restrictions for registration contains that "any mark, any indication or denomination of a plant variety is causing hurt to the religious feelings of any individual is not registrable".

In the Indian patent law, it is clear that the inventions which are against ethical and moral standards are not patentable. In India, no patent has been given on living being till date but no bar is there on patenting living beings. In the words of the former Chief Justice of the Supreme Court of India, "research, which promises to mankind the great blessings of science, should not be stifled by too restrictive approach (ICMR Guidelines, 2000).

\section{Winding Up:}

'Secularism' in the Indian Constitution has been defined and interpreted within its limitations as a constitutional safeguard for the protection of religious, moral and ethical values of the citizens. Though it is limited in the initial days of interpretation to sociological perspective of protection only, now due to the advancement of science as explained above, expansion of the same became inevitable. The technological advancement particularly in the field of biotechnology and genomics is expanding more and intruding into the personal life of the individuals from all respects such as their genome mapping, identification of the DNA structuring, storing of medical history or medical database etc., which is helpful for the man to know about himself and understand the colours of metabolic life in a better way to cure the unknown diseases which are emerging. But the other side of the coin to the technological advancement is the unnatural creations of the scientists such as human cloning, chimeras etc., which cannot be accepted from the point of view of 'public order and morality' which is required to the governed to protect the 'society' as well as 'secular' feelings of the citizens at large. Indian Intellectual Property Legislations are keen in controlling the innovations which cause damage to the religious and moral values of the citizens. In the global scenario also, the countries like United States, United Kingdom, Japan etc, are trying the to control the immoral side of the scientific advancement with the weapon of 'secularism' and protection of 'religious feelings' by obstructing the Intellectual Property protection to such innovations.

\section{Reference}

[1]. Director-General Indian Council of Medical Research, "Ethical Guidelines for Biomedical Research on Human Participants", (2006.) Available at http://icmr.nic.in/ethical_guidelines.pdf.

[2]. George P. Smith II, "Law, Medicine and Religion : Towards a Dialogue and Partnership in Biomedical Technology and Decision making", 21, Journal of Contemporary Health Law and Policy, Spring, 2005, p. 169.

[3]. Pankaj Mishra, "How India Reconciles Hindu Values and Biotech". The New York Times (August 21, 2005). Available at http://www.nytimes.com/2005/08/21/weekinreview/21 mishra.html? pagewanted=all\&_r=0

[4]. Peter D. Schmid, "Religion, Secular Humanism and the First Amendment", 13, Southern Illinois University Law Journal, Winter, 1989, p.357.

[5]. Section 9 of the Trademarks Act, 1999. Available at http://www.indiankanoon.org/doc/1158841/

[6]. Section 9 of the Geographical Indications of Goods (Registration and Protection) Act, 1999. Available at http://www.wipo.int/wipolex/en/text.jsp?file_id=128105

[7]. Section 15(4) of the Protection of Plant Varieties and Farmer's Rights Act, 2001. Available at http://agricoop.nic.in/PPV\&FR\%20Act,\%202001.pdf

[8]. Section 3 of the Indian Patent Act, 1970. Available at http://ipindia.nic.in/ipr/patent/patent_Act_1970_28012013_book.pdf

[9]. Watson.J.D and Crick.F.H., "A Structure for Deoxyribose Nucleic Acid", Nature, 1953, 171 : 737-738.

[10]. Whitehead \& Conlan, "The Establishment of the Religion of Secular Humanism and Its First Amendment Implications", 10 Texas Technology Law Review 1, 1978, p.30, n.162. 